\title{
Effect of Calcium Ions on Growth and Metabolism of Saccharomyces carlsbergensis
}

\author{
By RACHEL LOTAN \\ Department of Food Technology, Technion - Institute of Technology, \\ Haifa, Israel
}

\author{
ISRAELA BERDICEVSKY AND D. MERZBACH
}

Department of Microbiology, Technion - The Aba Khoushy School of Medicine, Haifa, Israel

AND N. GROSSOWICZ

Department of Bacteriology, The Hebrew University - Hadassah Medical School, Jerusalem, Israel

(Received 17 March 1975; revised II August 1975)

\section{SUMMARY}

Addition of calcium ions increased 2- to 3-fold the growth of Saccharomyces carlsbergensis $2 \mathrm{I}$ in a minimal glucose-containing medium. The minimal concentration enhancing growth was 25 to $50 \mu \mathrm{g} / \mathrm{ml} \mathrm{CaCl}$. Other divalent and trivalent cations tested, except for strontium ions, did not duplicate the calcium effect. Actively growing and dividing cells took up ${ }^{45} \mathrm{Ca}^{2+}$, while resting yeast cells did not. The radiocalcium taken up was incorporated into newly synthesized structural material, presumably into the membrane protein.

\section{INTRODUCTION}

Calcium ions protect yeast membranes from disruption by polyenes or butanol (Caraffoli et al. 1970). This cation also prevents leakage of cellular material from yeast suspended in glucose (Lewis \& Stephanopoulos, 1967). Calcium ions also increase membrane damage caused by methyl phenidate (Spoerl, 197I). In addition to the effect on the membrane, calcium ions activate certain important enzymic reactions like ATPase (Caraffoli et al. 1970).

This paper describes the effect of calcium ions on growth of Saccharomyces carlsbergensis 21 and on the incorporation of ${ }^{45} \mathrm{Ca}^{2+}$ into the cellular material of the yeast cell.

\section{METHODS}

Radiochemicals. ${ }^{45} \mathrm{CaCl}_{2}$ was purchased from the Radiochemical Centre, Amersham, Buckinghamshire.

Organism. Saccharomyces carlsbergensis 2I was obtained from Professor M. Aschner, Department of Food Technology, Technion, Haifa, Israel.

The minimal medium was composed of $(\mathrm{g} / 100 \mathrm{ml})$ : glucose, $\mathrm{I} ;\left(\mathrm{NH}_{4}\right)_{2} \mathrm{SO}_{4}, 0.2 ; \mathrm{K}_{2} \mathrm{HPO}_{4}$, 0.1 ; $\mathrm{MgSO}_{4} .7 \mathrm{H}_{2} \mathrm{O}, 0.02$; distilled water was added to $100 \mathrm{ml}$ and the $\mathrm{pH}$ adjusted to 7.0 ; the medium was sterilized for $15 \mathrm{~min}$ at $121{ }^{\circ} \mathrm{C}$.

The vitamin mixture was sterilized by Millipore filtration and added aseptically to the minimal medium to give the following final concentrations $(\mu \mathrm{g} / \mathrm{ml})$ : thiamine hydrochloride, 
0.5 ; riboflavine, 0.5 ; calcium pantothenate, 0.5 ; niacin, 0.5 ; pyridoxal phosphate, 0.1 ; p-aminobenzoic acid, 0.1 ; inositol, 0.1 ; folic acid, 0.01 ; and biotin, 0.04 .

Growth conditions. Saccharomyces carlsbergensis $2 \mathrm{I}$ was grown in $250 \mathrm{ml}$ Erlenmeyer flasks containing $50 \mathrm{ml}$ minimal medium and incubated at $30^{\circ} \mathrm{C}$ on a rotary shaker. Growth was measured turbidimetrically in a Klett-Summerson colorimeter at $660 \mathrm{~nm}$. The overnight growth on solid agar (containing $\mathrm{CaCl}_{2}$ ) was suspended in $50 \mathrm{ml}$ sterile water, diluted to contain $2 \times 10^{4}$ cells $/ \mathrm{ml}$ and used as an inoculum.

Cell-free extract. Yeasts grown for $6 \mathrm{~h}$ in the minimal medium in the presence of ${ }^{45} \mathrm{CaCl}_{2}$ were washed twice with $0.2 \mathrm{M}$-citrate-phosphate buffer, $\mathrm{pH} 7 \cdot 0$. Sphaeroplasts were prepared as described below. After disruption by sonication the whole mixture was centrifuged for Io min at $20000 \mathrm{~g}$ and the radioactivities in the supernatant and pellet were determined.

Preparation of sphaeroplasts. Sphaeroplasts were obtained from exponentially growing cells by the method of Cabib (I97I). For each gram of yeasts (wet weight) $1.4 \mathrm{ml}$ of 0.1 M-EDTA and $0.024 \mathrm{ml}$ of 2-mercaptoethanol were added and the volume made up to $3.5 \mathrm{ml}$ with distilled water. The mixture was incubated for $30 \mathrm{~min}$ at $30^{\circ} \mathrm{C}$ with shaking and then centrifuged, in the cold, for $10 \mathrm{~min}$ at $20000 \mathrm{~g}$. The pellet was washed once with $5 \mathrm{ml}$ of $10 \%$ mannitol, then placed in a mixture consisting of $(\mathrm{ml})$ : citrate-phosphate buffer, pH 6.I, 0.57; 0.I M-EDTA, 0.067; snail gut juice (SUC d'Helix Pomatia, L'Industrie Biologique Francaise, Gennevilliers, France) $0.3 ; 20 \%$ mannitol, 0.94; $10 \%$ mannitol solution to give a total volume of $6.7 \mathrm{ml}$. The suspension was incubated at $30^{\circ} \mathrm{C}$ on a reciprocating shaker at low speed, to prevent the suspension from settling. The sphaeroplasts obtained were centrifuged at $1000 \mathrm{~g}$ for $10 \mathrm{~min}$ and washed three times with $10 \%$ mannitol containing citrate-phosphate buffer.

Measurement of ${ }^{45} \mathrm{CaCl}_{2}$ incorporation. During incubation of the culture, samples of yeast cells were filtered through Millipore membranes $(0.45 \mu \mathrm{m})$ and washed three times with $5 \mathrm{ml}$ of $0.85 \%(\mathrm{w} / \mathrm{v}) \mathrm{NaCl}$. The filters were dried for $45 \mathrm{~min}$ at $45^{\circ} \mathrm{C}$ and counted in a Packard Tricarb scintillation counter. Two different scintillation mixtures were used. For the intact cells a toluene scintillator containing $3 \mathrm{~g}$ PPO and $0.1 \mathrm{~g}$ POPOP/l was used, while a dioxane scintillator containing $\mathrm{I} 20 \mathrm{~g}$ naphthalene, $7 \mathrm{~g}$ PPO and $50 \mathrm{mg}$ POPOP/l was used for the cell-free extract.

\section{RESULTS}

\section{Effect of calcium ions on growth of Saccharomyces carlsbergensis $2 \mathrm{I}$}

The yeast strain grew in the minimal medium without added calcium ions. However, addition of $500 \mu \mathrm{g} \mathrm{CaCl}_{2} / \mathrm{ml}$ to the medium caused a considerable increase in the growth of the yeast (Fig. I). The addition of $25 \mu \mathrm{g}$ caused some increase (Fig. 2). Growth of cultures containing added calcium and control cultures was similar during the first $8 \mathrm{~h}$ of incubation, but upon further incubation only the calcium-containing cultures continued to grow (Fig. I). It was therefore assumed that the cessation of growth in the control cultures resulted from depletion of calcium ions due to growth of the inoculum from a calcium-containing medium. The resumption of growth of these cultures on the addition of calcium ions supports this hypothesis.

There seemed to be no critical period for the addition of calcium ions to calcium-depleted cultures; addition of the cation to control cultures $3 \mathrm{~h}$ after inoculation resulted in growth almost equal to that found in cultures which received the cation at zero time. When addition of the cation was delayed for $10 \mathrm{~h}$, the calcium-dependent growth was resumed after a considerable lag (Fig. 3). 


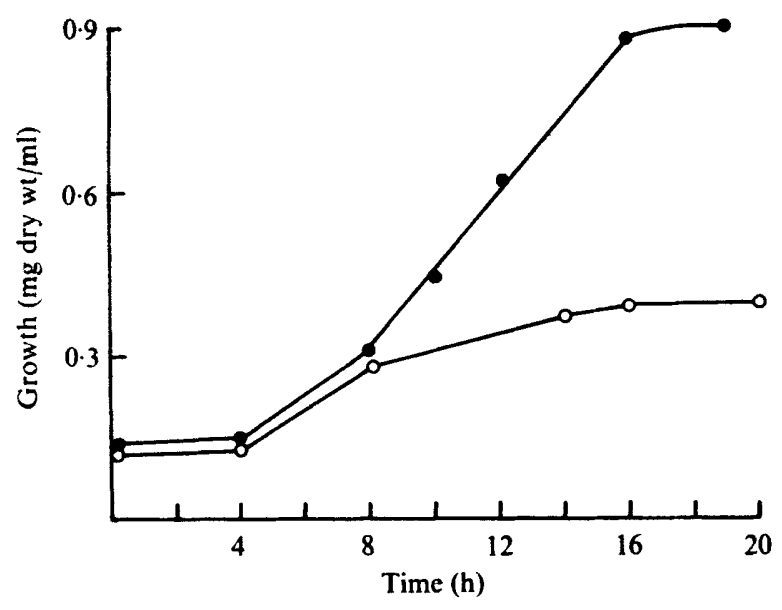

Fig. I

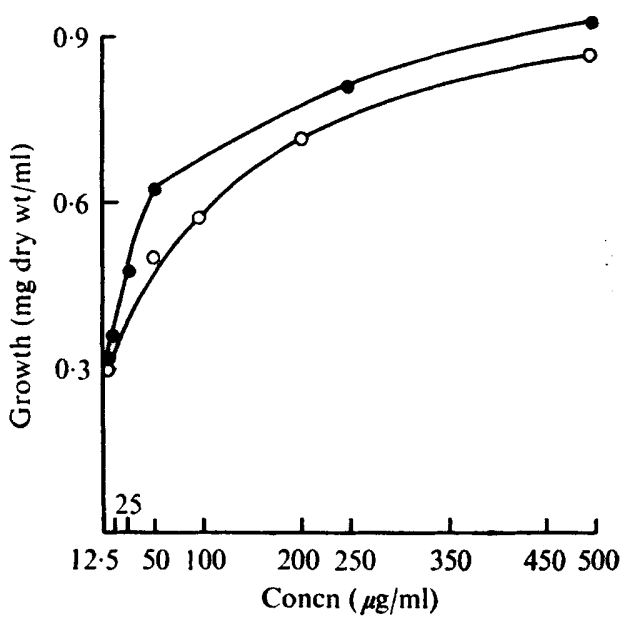

Fig. 2

Fig. I. Effect of $\mathrm{CaCl}_{2}$ and incubation time on the growth of $S$. carlsbergensis 21. $\bigcirc$, Control (no $\mathrm{CaCl}_{2}$ added); 9 , with $\mathrm{CaCl}_{2}(500 \mu \mathrm{g} / \mathrm{ml})$.

Fig. 2. Effect of increasing concentrations of (O) $\mathrm{CaCl}_{2}$ and $(O) \mathrm{SrCl}_{2}$ on the growth of $S$. carlsbergensis. Growth was measured after $18 \mathrm{~h}$.

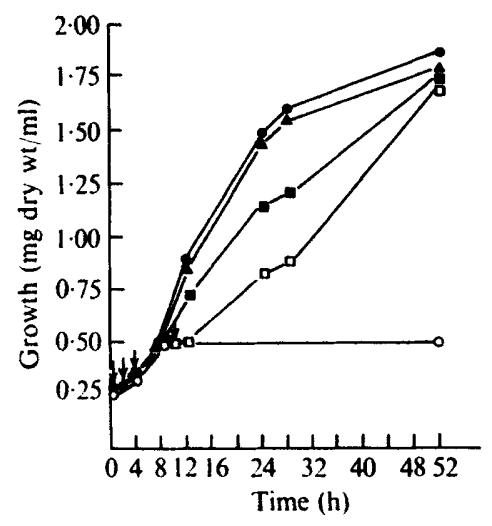

Fig. 3

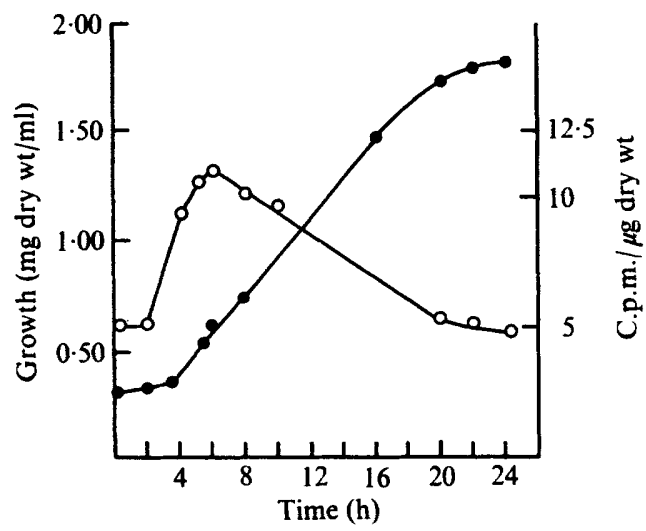

Fig. 4

Fig. 3. Effect of time of addition (indicated by arrows) of $\mathrm{CaCl}_{2}(500 \mu \mathrm{g} / \mathrm{ml})$ on the growth of $S$. carlsbergensis. $\mathrm{CaCl}_{2}$ added after (h);, $0 ; \Delta, 3 ; \mathbf{\square}, 4.5 ; \square, 10 . \mathrm{O}$, Control (no $\mathrm{CaCl}_{2}$ added).

Fig. 4. Uptake of ${ }^{45} \mathrm{Ca}^{2+}$ during growth of $\mathrm{S}$. carlsbergensis. $\odot$, Growth in presence of $\mathrm{CaCl}_{2}$; $\mathrm{O}$, uptake of ${ }^{45} \mathrm{Ca}^{2+}$ during growth, measured as c.p.m. $/ \mu \mathrm{g}$ dry wt.

\section{Specificity of the calcium effect}

The effect of calcium ions on growth of the yeast strain was found to be specific. Except for the closely related strontium ion, which showed a quantitatively similar effect on growth (Fig. 2), none of a variety of divalent $\left(\mathrm{Mn}^{2+}, \mathrm{Mg}^{2+}\right)$ and trivalent $\left(\mathrm{Co}^{3+}, \mathrm{Fe}^{3+}\right)$ cations tested duplicated the calcium effect. The effect of $\mathrm{Ba}^{2+}$ was difficult to assess because of the rapid precipitate that was formed upon addition of the cation, but it seemed that $\mathrm{Ba}^{2+}$ could not substitute for $\mathrm{Ca}^{2+}$. Cobalt ions were inhibitory at low concentrations $(5 \mu \mathrm{g} / \mathrm{ml})$ while manganese and ferric ions only had inhibitory effects at high concentrations (500 and 
Table I. ${ }^{45} \mathrm{Ca}^{2+}$ in various fractions of $\mathrm{S}$. carlsbergensis $2 \mathrm{I}$

\begin{tabular}{lr}
\multicolumn{1}{c}{ Fraction } & C.p.m./ml \\
Intact cells (pellet) & 390 \\
Supernatant (after removal of cells) & 65 \\
Sphaeroplasts (pellet) & 320 \\
Sphaeroplast supernatant & 104 \\
Sphaeroplast lysate & 225 \\
High-speed supernatant (20000 g) & \\
from sphaeroplast lysate & 25
\end{tabular}

$750 \mu \mathrm{g} / \mathrm{ml}$, respectively). Magnesium ions, although essential for growth (optimal concentration $200 \mu \mathrm{g} / \mathrm{ml}$ ) even in the presence of calcium, could not substitute for the latter cation.

Addition of EDTA decreased the growth of $S$. carlsbergensis $2 \mathrm{I}$ in both unsupplemented and calcium-supplemented media. The effect of EDTA was considerably more marked when added to calcium-depleted cultures, causing up to $60 \%$ inhibition of growth at a concentration of $500 \mu \mathrm{g} / \mathrm{ml}$. EDTA probably removed all the available calcium present as a contaminant in the medium and perhaps mobilized some intracellular calcium. Since a large excess of calcium ions was required to abolish the EDTA-produced inhibition it seems that the chelating agent affected the critical concentration of the other essential cations as well.

$$
\text { Uptake of }{ }^{45} \mathrm{Ca}^{2+} \text { by yeast }
$$

Since calcium ions specifically enhanced the growth of the yeast $S$. carlsbergensis $2 \mathrm{I}$, we investigated whether the cells were able to incorporate radioactive calcium.

Non-proliferating yeast cells were resuspended in the minimal medium containing ${ }^{45} \mathrm{Ca}^{2+}$. The radioactivity of the cells was very low and it decreased to background levels after washing in the presence of EDTA or non-radioactive calcium.

In contrast growing yeast cells showed a considerable uptake of the cation. Under the experimental conditions used, maximum uptake of ${ }^{45} \mathrm{Ca}^{2+}$ was found after 4 to $10 \mathrm{~h}$ incubation with a peak after $6 \mathrm{~h}$, during the early exponential phase of the culture (Fig. 4). The calcium taken up during growth was found to be firmly bound to the yeast cells; attempts to remove the radiocalcium by treatment with EDTA failed, and it was also non-exchangeable with excess non-radioactive $\mathrm{Ca}^{2+}$.

\section{Localization of ${ }^{45} \mathrm{Ca}^{2+}$ within the yeast cell}

Yeast cells grown in the presence of ${ }^{45} \mathrm{Ca}^{2+}$ for $6 \mathrm{~h}$ were centrifuged, washed with $0.2 \mathrm{M}$ citrate-phosphate buffer, $\mathrm{pH} 7 \cdot 0$, and treated with snail enzyme. The resulting sphaeroplasts were lysed and the lysate was subjected to differential centrifugation and assayed for radioactivity (Table I). Since no radioactivity was found in the supernatant after centrifugation for $30 \mathrm{~min}$ at $20000 \mathrm{~g}$ and the cell debris was radioactive, the ${ }^{45} \mathrm{Ca}^{2+}$ seems to be associated with the cell membrane and/or the mitochondria in the pellet.

\section{Effect of calcium ions on yeast structure}

Cells grown in the presence and absence of $\mathrm{CaCl}_{2}$ were examined under the microscope after incubation for $24 \mathrm{~h}$. Cells grown in the presence of $\mathrm{Ca}^{2+}$ appeared intact and their membranes were highly refractile, whereas most cells grown in its absence showed signs of damage and had less refractile membranes. 


\section{DISCUSSION}

Since the irreversible uptake of ${ }^{45} \mathrm{Ca}^{2+}$ by the yeast cells was restricted to the phase of active growth and division, the calcium ion was probably taken up by cellular structures synthesized during that period. The most likely site appears to be the polypeptide in the membrane (Manery, 1966).

Studies on the mechanism of action of polyene antibiotics on a related yeast, Debaryomyces nicotianae, revealed that calcium ions compete with the antimycotic agent for a particular site on the membrane (Berdicevsky \& Grossowicz, 1972). The association of the calcium radioactivity of the digested and lysed sphaeroplasts with the sedimenting particles $\left(20000 \mathrm{~g}\right.$ ) also supports the location of ${ }^{45} \mathrm{Ca}^{2+}$ on the membrane. Moreover, since no decrease in the radioactivity of the particulate fraction occurred after cell wall digestion, we may exclude the wall as a possible site for calcium deposition during growth.

\section{REFERENCES}

Berdicevsky, I. \& Grossowicz, N. (1972). Reversal by calcium ions of the growth inhibition of Debaryomyces nicotianae caused by antifungal polyenes. Antimicrobial Agents and Chemotherapy 2, I-7.

Caraffoli, E., Balcavage, W. X., Lehninger, A. L. \& Matoon, J. R. (1970). $\mathrm{Ca}^{2+}$ metabolism in yeast cells and mitochondria. Biochimica et biophysica acta 205, I8-26.

CaBiB, E. (1971). Yeast spheroplasts. In Methods in Enzymology, vol. 22, pp. 120-122. Edited by W. B. Jacoby. New York and London: Academic Press.

LEWIS, M. J. \& Stephanopoulos, D. (1967). Glucose-induced release of amino acids from Saccharomyces carlsbergensis by action on the cytoplasmic membrane. Journal of Bacteriology 93, 976-984.

MANERY, J. F. (1966). Effects of Ca ions on membranes. Federation Proceedings 25, I 804-1 810.

SPOERL, E. (1971). Disruption of yeast membranes by methylphenidate. Journal of Bacteriology 105, I 68 1174. 